\title{
Chromosome Numbers of Some Southernmost Species of Mimosa L. (Leguminosae)
}

\author{
Guillermo Seijo* and Aveliano Fernández \\ Instituto de Botánica del Nordeste CC209, Sargento Cabral 2131. 3400 Corrientes, Argentina
}

Accepted October 26, 2000

\begin{abstract}
Summary Chromosome numbers of 9 species of Mimosa which grow in the southern limit of the South American centre of diversification were determined, all of them are new reports except the one of $M$. oligophylla. M. vellosiella, M. oligophylla and $M$. flagellaris were diploids with $2 n=2 x=26$; M. velloziana and $M$. adpress $a$ were tetraploids with $2 n=4 x=52 ;$. sprengelii, M. ramulosa and $M$. rocae were octoploids with $2 n=8 x=104$; and one accession of $M$. balansae was diploid while the other was tetraploid. All of them were multiples of the basic chromosome number $x=13$. The polyploid species were more frequent at higher latitudes, this increment was also accompanied with a higher ploidy level of the polyploids southernward. All the polyploids found belong to the sections with most advanced characters of the genus, which supports the phylogeny proposed for Mimosa by Barneby. Data suggest that the extension of the genus toward the temperate zones might have be done mainly by polyploid species, which may have had advantages over the diploids in colonising habitats restricted to the latter.
\end{abstract}

Key words Chromosome numbers, Mimosa, Polyploidy.

The genus Mimosa, which comprise around 500 species and several subspecies and varieties, has 5 diversification centres. The largest centre is situated in South America, which extends from the South of the Brazilian Amazon and adjacent Paraguay through the rest of the continent until the southern temperate areas. The second largest centre is located in Mexico which extends to Central and North America. There are 3 other smaller centres located in Cuba, Orinoco river basin and Madagascar. The latter is the only extra Neotroprical centre of diversification of the genus (Barneby 1991).

Chromosome numbers in Mimosa have been mainly reported for subtropical species. These numbers range from diploids $2 n=26$ to octoploids with $2 n=104$ (Fedorov 1974, Goldblatt 1984, 1985, 1988, Goldblatt and Johnson 1990, 1991, Moore 1973, 1977, Seijo 1993, 1999), which evidence that polyploidy had played an important role in the evolution of the genus.

In some groups of higher plants, variation of the ploidy level or the frequency of polyploids accompanied changes in latitude or altitude. The increment of polyploid frequency is also reported to increase with latitude when floras are considered as a whole (Löve and Löve 1957, Hanelt 1966). Nevertheless, other authors claim that these correlations are far from being a generalization (Faberger 1957, Stebbins 1971, Grant 1971).

Considering that, in the present work the chromosome numbers of the southern Mimosa species from Argentina and Uruguay were studied and the species ploidy level were analysed in relation to their distribution.

Materials and methods

The studied material and the localities of collection are detailed in Table 1. Vouchers of the

* Corresponding author. 
Table 1. Chromosome numbers and localities of the studied material

\begin{tabular}{|c|c|c|c|}
\hline \multirow{2}{*}{ Species } & \multicolumn{2}{|c|}{$2 n$} & \multirow{2}{*}{ Collectionist Localities and Herbaria } \\
\hline & Mitosis & Meiosis & \\
\hline \multicolumn{4}{|l|}{ Sect. Habbasia } \\
\hline \multirow[t]{2}{*}{ M. vellosiella Burkart } & 26 & & $\begin{array}{l}\text { S. 1006. Argentina, Chaco, Dpto } 1 \text { ro. de Mayo. } \\
\text { Colonia Benítez. (CTES, NY) }\end{array}$ \\
\hline & 26 & & $\begin{array}{l}\text { S. 1015. Argentina, Chaco, Dpto. Cap. Antequeras. } \\
\text { (CTES, LIL, BAB) }\end{array}$ \\
\hline \multicolumn{4}{|l|}{ Sect. Mimosa } \\
\hline \multicolumn{4}{|l|}{ Ser. Pedunculosae } \\
\hline \multicolumn{4}{|l|}{ Subser. Pedunculosae } \\
\hline M. oligophylla Micheli & 26 & & $\begin{array}{l}\text { S. 1021. Argentina, Corrientes, Dpto. Capital. } \\
\text { Molina Punta. (CTES, MO) }\end{array}$ \\
\hline M. flagellaris Benth. & 26 & & $\begin{array}{l}\text { S. 994. Argentina, Corrientes, Dpto. } \\
\text { Mercedes. (CTES, BAB, NY) }\end{array}$ \\
\hline \multicolumn{4}{|l|}{ Subser. Polycarpae } \\
\hline \multirow[t]{2}{*}{ M. balansae Micheli } & 26 & & $\begin{array}{l}\text { S. 992. Argentina, Corrientes, Dpto. Mercedes. } \\
\text { (CTES, UNSL, CANB) }\end{array}$ \\
\hline & 52 & $26 \mathrm{II}$ & $\begin{array}{l}\text { A. 6031. Argentina, Corrientes. Beron de Astrada. } \\
\text { (CTES, CANB, NY) }\end{array}$ \\
\hline \multicolumn{4}{|r|}{ (CILS, CIND, IV) } \\
\hline \multicolumn{4}{|l|}{ Subser. Mimosa } \\
\hline \multirow[t]{2}{*}{ M. velloziana Mart. } & 52 & 26 II & $\begin{array}{l}\text { S. 1033. Argentina, Corrientes.Dpto. San Cosme. } \\
\text { (CTES, ASU, CANB) }\end{array}$ \\
\hline & 52 & & $\begin{array}{l}\text { K. 41913. Argentina, Corrientes. Dpto. San Cosme. } \\
\text { Paso de la Patria. (CTES, HAS, SPF) }\end{array}$ \\
\hline \multicolumn{4}{|l|}{ Subser. Obstrigosae } \\
\hline M. adpressa Hook. et Arn. & & $26 \mathrm{II}$ & $\begin{array}{l}\text { S. 997. Argentina, Entre Ríos, Dpto. } \\
\text { Concepción, Banco Pelay. (CTES, ICN, NY) }\end{array}$ \\
\hline M. ramulosa Benth. & & $52 \mathrm{II}$ & $\begin{array}{l}\text { S. 999. R. O. Uruguay, Dpto. Minas. Cerro Verdún. } \\
\text { (CTES, BAB, NY) }\end{array}$ \\
\hline & & $52 \mathrm{II}$ & S.1003. R. O. Uruguay, Dpto. Lavalleja. (CTES, ICN,NY) \\
\hline M. sprengelii DC. & & $52 \mathrm{II}$ & S. 1002. R. O. Uruguay, Dpto. Lavalleja. (CTES, ASU, NY) \\
\hline \multicolumn{4}{|l|}{ Sect. Calothamnos } \\
\hline M. rocae Lorentz et Nied. & 104 & & $\begin{array}{l}\text { S. 110. Argentina, Bs. As. Pdo. Cnel. Suárez. } \\
\text { Sa. de la Ventana. (CTES, MNES) }\end{array}$ \\
\hline
\end{tabular}

K.: Krapovickas, A.; S.: Seijo, G.; A.: Arbo, M.

studied specimens are kept in the herbarium of the Instituto de Botánica del Nordeste (CTES) and duplicates are retained in different herbaria (Table 1). For meiotic studies floral buds were fixed in 5:1 ethanol : lactic acid (Fernández 1973) for at least $24 \mathrm{~h}$ and kept in 70\% aqueous ethanol until use. Pollen mother cells were stained with $3 \%$ acetic carmine and permanent slides were made using Venetian Turpentine as mounting medium. For determinations of somatic chromosome numbers, root tips of germinated seeds were pre-treated with $0.002 \mathrm{M}$ 8-hydroxyquinoline for 4 to $6 \mathrm{~h}$ at room temperature, then fixed in ethanol : lactic acid $(5: 1)$ and kept in $70 \%$ aqueous ethanol. Roots were stained following the Feulgen technique and the meristems were macerated in a drop of $3 \%$ acetic orcein before squash. Permanent slides were prepared using Euparal as mounting medium.

\section{Results and discussion}

In this study the chromosome number of 13 accessions belonging to 9 species were determined (Table 1), all of them are new reports except the one for M. oligophylla which coincides with previous reports (Seijo 1999). M. vellosiella (Fig. 1A), M. oligophylla (Fig. 1B) and M. flagellaris 

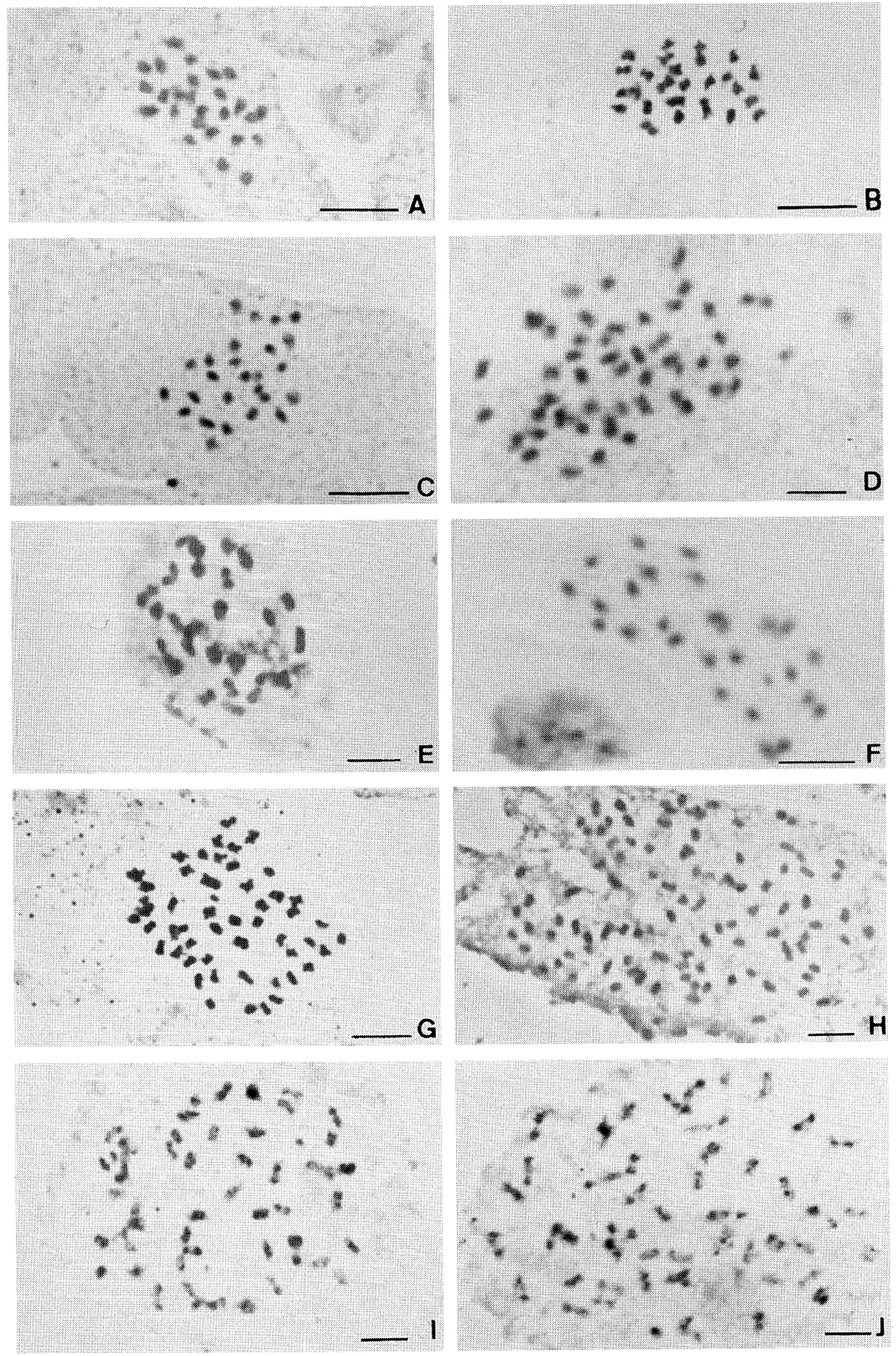

Fig. 1. Mitotic and meiotic chromosomes of Mimosa. A) M. vellosiella, $2 n=26$, B) M. oligophylla, $2 n=26$, C) $M$. flagellaris, $2 n=26$, D) $M$. velloziana, $2 n=52$, E) $M$. adpressa, diakinesis $2 n=26 \mathrm{II}$, F) $M$. balansae, diploid cytotype $2 n=26, \mathrm{G}) M$. balansae, tetraploid cytotype $2 n=52, \mathrm{H}) \mathrm{M}$. rocae, $2 n=104, \mathrm{I}$ )

M. sprengelii, diakinesis $2 n=52 \mathrm{II}, \mathrm{J}) \mathrm{M}$. ramulosa, diakinesis $2 n=52 \mathrm{II}$. Bar indicates $5 \mu \mathrm{m}$. 
(Fig. 1C) were diploids with $2 n=2 x=26$; M. velloziana (Fig. 1D) and M. adpressa (Fig. 1E) were tetraploids with $2 n=4 x=52 ; M$. sprengelii (Fig. 1I), M. ramulosa (Fig. 1J) and $M$. rocae (Fig. 1H) were octoploids with $2 n=8 x=104$; and one accession of $M$. balansae was diploid (Fig. 1F) while the other was tetraploid (Fig. 1G). M. vellosiella belongs to Sect. Habbasia, which species present intermediate characters between the ancestral and advanced Sections. The other studied species belong to Sect. Mimosa and Sect. Calothamnos, both situated at the top of the evolutive line proposed for the genus by Barneby (1991). The distribution of the ploidy level of the studied species is presented in Fig. 2.

Three out of the 5 species collected in the north of Argentina (Chaco and Corrientes Provinces, between $27^{\circ}$ and $29^{\circ} \mathrm{S}$ ), M. vellosiella, $M$. oligophylla and $M$. flagelaris, were diploids; $M$. velloziana was tetraploid; and $M$. balansae had one diploid and one tetraploid accessions. $M$. vellosiella is a shrub which grows characteristically on muddy and sandy river banks and stuary shores, locally abundant along río Paraná from $22^{\circ} \mathrm{S}$ to the delta and the south shore of río de la

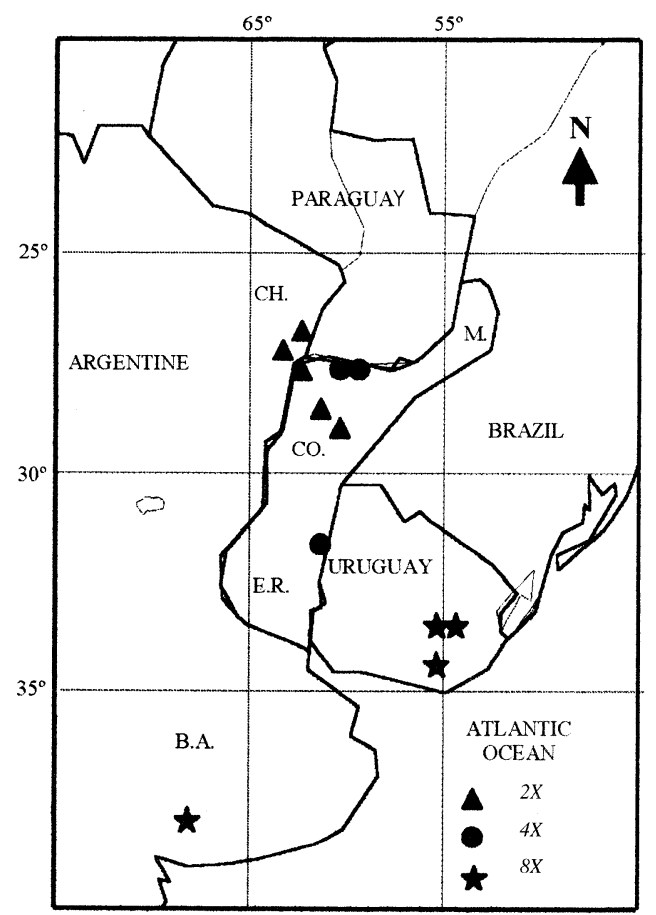

Fig. 2. Map representing the ploidy level distribution of the studied species. Abbreviations of provinces names: B.A.: Buenos Aires, CH.: Chaco, CO.: Corrientes, E.R.: Entre Rios, M.: Misiones. Plata. M. velloziana is an opportunistic weed, which forms diffuse tangles of prickly or sarmentose stems; and has an ample distribution from Mexico to northern Argentina. M. oligophylla, M. flagellaris and M. balansae are herbs which grow in campos of northern Argentina and southern Paraguay and Brazil. The diploid cytotype of M. balansae is more robust than the tetraploid which is an hemifuse herb, however, both cytotypes are ecologically very similar and grow mainly in sandy roadsides.

Southernward, in Entre Ríos Province (Argentina) and Uruguay which are approximately at the same latitude (between $32^{\circ}$ and $35^{\circ} \mathrm{S}$ ), 3 species were studied. Mimosa sprengelii and M. ramulosa were octoploids while $M$. adpressa was tetraploid. M. sprengelii and M. ramulosa were collected in Uruguay's hills, the first one grows in stony campos and at edges of thickets at low elevations while the second on open stony hillsides. M. adpressa on the other hand was collected in Entre Ríos Province, Argentina, in an open shore of Uruguay river, where it was forming prickly thickets.

M. rocae was also octoploid and it was collected in Ventania Hills, the southernmost limit of distribution of the genus $\left(38.5^{\circ} \mathrm{S}\right)$. It grows as a prostrate matted shrublet in places with thin stony soil and on exposed arenitic rock near $500 \mathrm{~m}$ high.

Considering the total of species studied in this report, polyploids were more frequent $(66 \%)$ than diploids. The latter were collected in subtropical areas or near so, being predominant over the polyploids. In previous reports, it has been found that 4 out of 14 species studied from Misiones, one of the northernmost and subtropical Provinces of Argentina, were polyploids (Seijo 1993, 1999). This only represent $28 \%$ of polyploid species, which is significantly lower than the percentage found in this report.

The studied species showed that the frequency of polyploids increased with the latitude, being the southern species only polyploids. This fact was also accompanied by increments of the ploidy level. In the northern and central areas of the study, the species were diploids and tetraploids, while 
at southern latitudes all species were octoploids. On the other hand, it appear to be no relationship between ploidy level and growth habit, since most of the ploidy levels were found both in herbs and shrubs.

All the species analyzed in the present report have chromosome numbers multiple of $x=13$, which has been previously proposed as the basic chromosome number for the genus (Isely 1971, Lewis and Elias 1981, Goldblatt 1981, Seijo 1993). Considering $x=7$ as the ancestral basic number for legumes, the diploid chromosome number $2 n=26$ may be a paleotetraploid and $x=13$ may be a derived basic chromosome number originated from an aneuploid reduction of $2 n=4 x=28$ (Goldblatt 1981).

The results presented here show that in the analysed Mimosa species, the polyploids frequency as well as the ploidy level increase with the latitude. This relation can be interpreted at the light of the believed greater tolerance of polyploids to marginal ecological conditions. Mimosa is a genus constituted mainly by tropical and subtropical species, which might have extended toward temperate habitats mainly by polyploid species. This is in accordance with the common assumption that polyploids have higher ability to colonise environments restrained to the diploid or lower polyploid parental.

\section{Acknowledgements}

The authors are grateful to Consejo Nacional de Investigaciones Científicas y Técnicas (CONICET), Argentina, and to Secretaría General de Ciencia y Técnica, Universidad Nacional del Nordeste for financial support.

\section{References}

Barneby, E. 1991. Sensitivae Censitae (Mimosa). Memoirs of New York Botanical Garden. 65: 1-835.

Faberger, C. 1957. Sur le Poucentage des Polyploides dans la Flore de L'ëtage des Alpes Suisses. Proc. VII Internat. Bot. Congr., pp. 51-58.

Fedorov, A. (ed.) 1974. Chromosome Numbers in Flowering Plants, O. Koeltz. Sci. Publ., Koeningseing. pp. 1-928.

Fernández, A. 1973. El ácido láctico como fijador cromosómico. Bol. Soc. Argent. Bot. 15: 287-290.

Goldblatt, P. 1981. Cytology and the Phylogeny of Leguminosae. In: Polhill, R. M. and Raven, P. H. (eds.). Advances in Legume Systematics, Part 2. Royal Botanical Garden, Kew. pp. 427-464.

- (ed.) 1984. Index to Plant Chromosome Numbers. 1979-1981. Monogr. Syst. Bot. Missouri Bot. Gard. 8.

- (ed.) 1985. Index to Plant Chromosome Numbers. 1982-1983. Monogr. Syst. Bot. Missouri Bot. Gard. 13.

- (ed.) 1988. Index to Plant Chromosome Numbers. 1984-1985. Monogr. Syst. Bot. Missouri Bot. Gard. 13.

- and Johnson, D. E. (eds.) 1990. Index to Plant Chromosome Numbers. 1986-1987. Monogr. Syst. Bot. Missouri Bot. Gard. 23.

— and - (eds.) 1991. Index to Plant Chromosome Numbers. 1988-1989. Monogr. Syst. Bot. Missouri Bot. Gard. 40.

Grant, B. 1971. Plant Speciation. Columbia University Press.

Hanelt, P. 1966. Polyploidie-Frequenz und geographische Verbreitung bei höhereren Pflanzen. Biol. Rundsch. 4: $183-196$.

Isely, D. 1971. Legumes of the United States. IV. Mimosa. Amer. Midl. Naturalist 85: 410-424.

Lewis, G. P. and Elias, T. S. 1981. Tribe Mimoseae. In: Polhill, R. M. and Raven, P. H. (eds.), Advances in Legume Systematics, Part 1. Royal Botanical Garden, Kew. pp. 155-168.

Löve, A. and Löve, D. 1957. Artic polyploidy. Proc. Genet. Soc. Canada 2: 23-27.

Moore, R. E., (ed.) 1973. Index to Chromosome Numbers for 1967-1971. Regnum Veg. Vol. 90.

- 1977. Index to Plant Chromosome Numbers for 1973-1974. Regnum Veg. Vol. 96.

Seijo, G. 1993. Números cromosómicos en especies argentinas del género Mimosa (Leguminosae). Bol. Soc. Argent. Bot. 29: 219-223.

- 1999. Chromosome studies in argentinian species of Mimosa. Cytologia 64: 241-246.

Stebbins, G. L. 1971. Chromosome Evolution in Higher Plants. Edward Arnold Ltd., Bristol. 